\title{
THE EFFECTS OF TEACHING MARTIAL ARTS TECHNIQUES IN A SELECTED SAMPLE
}

\author{
Željko Mihaljčić
}

\author{
Police Academy, Ministry of the Interior, Repubic of Srpska, BH
}

\begin{abstract}
The aim of this research is to determine to what extent the implementation of the training of martial arts techniques will cause changes in the morphological characteristics and motor skills in the selected sample. The sample of respondents were cadets at the basic police training at the Police Training Unit - Police Academy for the Special Police Unit. The initial measurement of morphological characteristics and motor abilities was carried out at the beginning of the training, and the final measurement after completion of the first phase of training lasting fifteen weeks. All respondents went through the selection process, which differs from the selection for the police officer of general jurisdiction in that the cadets for the Special Police Unit pass through a psychophysical endurance test in extreme situations that lasts for seven days. The sample of variables is classified into five groups, one group being related to the morphological characteristics, and the remaining four groups of variables on motor abilities. It can be concluded that the teaching program of martial arts techniques in the selected sample caused statistically significant influence in most of the tested variables in favor of final measurement.
\end{abstract}

Key words: Special Police Unit, effects, martial arts, cadets, selected sample, police.

\section{INTRODUCTION}

The primary goal of this research was to determine the effects of training martial arts techniques on motor skills and morphological characteristics of the selected sample. The sample of respondents were cadets at the basic police training at the Police Training Unit - Police Academy for the Special Police Unit. All respondents went through four stages of testing, such as: medical examination of category A, testing of motor abilities, general information test and interview. After the successful completion of the previous four phases of the testing, cadets approach the final check that is reflected in the check of psychophysical endurance in extreme situations: it consists in bringing candidates into situations of psychophysical tension in which they are expected a certain form of behavior. During the examination, candidates solve specific tasks, and they are exposed to constant psychological and physical efforts. The training program in this research involved the training of martial arts techniques of cadets of basic police training for members of the Special Police Unit through the subject Special Physical Education. The SPE program lasts all three phases of the basic police training, and the aim is to train cadets that they can independently use physical strength with elements of martial arts and at the same time one of the most commonly used means of force during the execution of official tasks and the tasks of the police officer and only when legal conditions have been created. The research was conducted during the first phase of the training lasting 15 weeks and with the realized fund of 49 classes. To evaluate the effects of training martial arts techniques in the selected sample, a group of variables was used to evaluate certain morphological characteristics, the maximum isometric force, exposive strenght, repetitive strength and locomotion.

\section{METHODS}

During the training process the transfer of skills and knowledge from the SPE program, and depending on the complexity and connection of the elements that should form a logical sequence, different methods of learning apply. Learning of simple technical elements and motor programs was carried out using the synthetic method (methods of the whole), while in the training of complex elements of martial arts an analytical method (method of learning the whole by parts) was applied, but immediately after learning by parts, the learning of the technique as a whole. Starting from the specificity of the need for a police officer to effectively undertake security tasks and tasks in critical moment and the necessity for every use of force to be in accor- 
dance with the law, the SPE is divided into thematic areas and harmonized with legislation in five teaching areas. Areas are defined by a logical line from simple to complex, and during the first phase of the training in which the research was carried out three areas were carried out, which are: basic elements of the SPE program such is basic elements of the SPE program, defense against unarmed attackers and overcoming passive and active resistance.

Measurement of morphological characteristics and motor abilities was carried out during the first phase of basic police training, initial measurement at the beginning of training and finite measurements at the end of the first phase of training lasting fifteen weeks. The morphological characteristics were measured by the Tanita BC 418-MA III body composition analyzer and included measuring body weight, body mass index and measurement of fat percentage. The variables of the motor skills included in this study were those for which previous studies have been found to cover the area that dominates in professional work performed by the police (Milošević, 1988; Milošević \& Zulić, 1986, 89-92; Copay \& Charles, 2001, 32-39). The group of variables referring to the maximum isometric force was measured by a tensiometric probe with a maximum force of measurement of $7500 \mathrm{~nm}(\mathrm{~N})$ at a sensitivity range of $1.25 \mathrm{~N}$, and all raw data are archived on a computer, the data are automatically processed for each respondent after archiving individually, calculating the maximum achieved $F$ max. It consists of: a platform with a hook, a tensiometric probe, an electronic force display, a bar with a hook and a chain (Dopsaj et al. 2010). Explosion measurement was performed using the Physical Ability Test 02 - PAT 02 (UNO-LEX, Novi Sad, Serbia, according to Jankovic, 2015). The Ergo Timer Globus system was used to measure the movement speed of the respondent. Measurement of repetitive power is done using standardized capability tests such as: push up, abdominal muscle strength, chin up test. The locomotion was measured by the use of tests agility T- test, Cooper 12 minut test, ground agility test.

Basic statistical methods, descriptive statistics were applied such as mean, standard deviation, minimal and maximu values, range, skewness and kurtosis. For the determination of statistically significant differences in morphological characteristics and motor abilities between the subjects on the initial and final measurement, the $T$ test of paired samples was applied.

Table 1. Results of descriptive statistics of the selected sample

\begin{tabular}{|c|c|c|c|c|c|c|c|c|}
\hline Varible & Phase & Mean & SD & Min & Max & Range & Skew & Kurt \\
\hline \multirow{2}{*}{ fat $\%$} & initially & 11,03 & 2,81 & 7 & 17,5 & 10,5 & 0,34 & $-0,79$ \\
\hline & final & 12,46 & 3,12 & 7,1 & 18,9 & 11,8 & 0,4 & $-0,43$ \\
\hline \multirow{2}{*}{$\operatorname{tm}(\mathrm{kg})$} & initially & 81,91 & 7,18 & 71,9 & 98,3 & 26,4 & 0,41 & $-0,67$ \\
\hline & final & 83,73 & 7,38 & 72,2 & 99,6 & 27,4 & 0,26 & $-1,06$ \\
\hline \multirow{2}{*}{$\mathrm{BMI}(\mathrm{kg} / \mathrm{m} 2)$} & initially & 25,23 & 1,53 & 22,3 & 28,6 & 6,3 & 0,01 & $-0,49$ \\
\hline & final & 25,67 & 1,66 & 22,5 & 30,9 & 8,4 & 0,69 & 1,24 \\
\hline \multirow{2}{*}{$\begin{array}{l}\text { MrVu Fmax } \\
\text { (N) }\end{array}$} & initially & 144,59 & 23,4 & 94,2 & 204,2 & 110 & 0,05 & 0,14 \\
\hline & final & 151,31 & 20,45 & 96 & 201,3 & 105,3 & $-0,1$ & 0,49 \\
\hline \multirow{2}{*}{$\begin{array}{l}\text { Noge } \\
\text { Fmax }(\mathrm{N})\end{array}$} & initially & 129,15 & 25,3 & 68,8 & 186 & 117,2 & $-0,22$ & 0,51 \\
\hline & final & 136,53 & 19,49 & 98 & 173,1 & 75,1 & $-0,14$ & $-0,76$ \\
\hline \multirow{2}{*}{$\mathrm{t} 100(\mathrm{~s})$} & initially & 13,13 & 0,6 & 12,06 & 14,33 & 2,27 & $-0,12$ & $-0,64$ \\
\hline & final & 13,39 & 0,56 & 12,3 & 14,47 & 2,17 & 0,14 & $-0,53$ \\
\hline \multirow{2}{*}{ vis $(\mathrm{cm})$} & initially & 42,77 & 5,2 & 34,3 & 61,6 & 27,3 & 1,1 & 3 \\
\hline & final & 43,61 & 5,43 & 34 & 58 & 24 & 0,45 & 0,24 \\
\hline \multirow{2}{*}{ dalj $(\mathrm{cm})$} & initially & 235,5 & 12,6 & 209 & 272 & 63 & 0,87 & 1,6 \\
\hline & final & 244 & 12,1 & 228 & 280 & 52 & 1 & 0,93 \\
\hline \multirow{2}{*}{ zgib (rep) } & initially & 14,55 & 4,73 & 5 & 25 & 20 & 0,11 & $-0,06$ \\
\hline & final & 16,15 & 4,68 & 5 & 25 & 20 & $-0,05$ & $-0,21$ \\
\hline \multirow{2}{*}{ sklek (rep) } & initially & 46,25 & 9,28 & 24 & 63 & 39 & $-0,48$ & $-0,16$ \\
\hline & final & 57,6 & 9,87 & 27 & 75 & 48 & $-0,72$ & 1,41 \\
\hline
\end{tabular}




\begin{tabular}{|l|c|c|c|c|c|c|c|c|}
\hline \multirow{2}{*}{ ptsp (rep) } & initially & 49,43 & 6,06 & 40 & 64 & 24 & 0,65 & 0 \\
\cline { 2 - 9 } & final & 59,88 & 5,14 & 45 & 72 & 27 & $-0,38$ & 1,1 \\
\hline \multirow{2}{*}{ ttest (s) } & initially & 10,65 & 0,49 & 9,9 & 11,69 & 1,79 & 0,56 & $-0,37$ \\
\cline { 2 - 9 } & final & 10,09 & 0,49 & 9,16 & 11,25 & 2,09 & 0,55 & 0,23 \\
\hline \multirow{2}{*}{ pn (s) } & initially & 8,37 & 0,85 & 5,85 & 10,03 & 4,18 & $-0,39$ & 0,53 \\
\cline { 2 - 9 } & final & 8,31 & 0,75 & 6,62 & 10,32 & 3,7 & 0,46 & 0,88 \\
\hline \multirow{2}{*}{ oss (s) } & initially & 17,62 & 0,9 & 16,09 & 19,54 & 3,45 & 0,26 & $-0,73$ \\
\cline { 2 - 9 } & final & 17,22 & 0,94 & 15 & 20,15 & 5,15 & 0,48 & 1,38 \\
\hline \multirow{2}{*}{ kuper (m) } & initially & 2962,6 & 226,2 & 2720 & 3520 & 800 & 1,33 & 0,79 \\
\cline { 2 - 9 } & final & 2997,5 & 204,3 & 2670 & 3480 & 810 & 0,91 & 0,41 \\
\hline
\end{tabular}

Legend: Mean - aritmetical mean; SD - standard deviation; Min. - minimum value; Max. - maximum value; Range - range of results; Skew. - coefficient of curvature; Kutr. - coefficient of roundness.

Observing the results of descriptive statistics, it is results in the variables that were examining the lonoticeable that the difference between the results comotion, such as variable t100 (100 meter run). obtained on the final measurement in almost all variables. it is evident improvement of the mean DIFFRENCESS BETWEEN INITIAL value towards better results in variables that have AND FINAL MEASUREMENTS been testing certain types of strenght. On the other For the determination of statistically significant difhand, it is also evident that there has been an in- ferences in morphological characteristics and mocrease in the results of the morphological charac- tor abilities between the respondents at the initial teristics (fat\%, tm and BMI) of the sampled sample and final measurements, the T test of paired samwhich probably led to a slight deterioration of the ples was applied.

Table 2. Significance of differences in morphological characteristics, initial - final measurement (T-test of paired samples)

\begin{tabular}{|l|l|l|l|l|l|}
\hline \multicolumn{1}{|c|}{ Variable } & $\begin{array}{c}\text { Mean } \\
\text { Differences }\end{array}$ & \multicolumn{1}{|c|}{ SD } & \multicolumn{1}{c|}{ t } & \multicolumn{1}{c|}{ df } & $\begin{array}{c}\text { Sig. } \\
\text { (2-tailed) }\end{array}$ \\
\hline TM-I vs. TM-F & $-1,83$ & $\pm 2,40$ & $-4,811$ & 39 &, $000^{* *}$ \\
\hline BMI-I vs. BMI-F & $-0,43$ & $\pm 0,82$ & $-3,324$ & 39 &, $002^{* *}$ \\
\hline FAT-I vs. FAT-F & $-1,43$ & $\pm 1,73$ & $-5,230$ & 39 &, $000^{* *}$ \\
\hline
\end{tabular}

Legend: I-initiail measurement; $F$ - final measurement; Mean Differences - diffedence between aritmetica mean initial - final measurement; $S D$ - stanadard deviation; $t$-velue; $d f$ - number of degree of fridom; Sig. (2-tailed) - level of significance; ${ }^{*}$ - Sig. $<0.05 ;{ }^{*}-$ Sig. $<0.01$

Statistically significant differences in the morphol- lyzing the results obtained by the statistical proceogical characteristics of the subjects between the dure, statistically significant differences were found initial and final measurements were examined by for all variables in favor of the final measurement, the T-test of the paired samples (Table 2). By ana- at the significance level of 0.01 .

Table 3. Significance of differences in in maximum isometric force, initial - final measurement (T-test of paired samples)

\begin{tabular}{|l|c|c|c|c|c|}
\hline \multicolumn{1}{|c|}{ Variable } & $\begin{array}{c}\text { Mean } \\
\text { Differences }\end{array}$ & SD & t & df & $\begin{array}{c}\text { Sig. } \\
\text { (2-tailed) }\end{array}$ \\
\hline $\begin{array}{l}\mathrm{F}_{\text {max }} \text { LEĐA-I vs. } \\
\mathrm{F}_{\text {max }} \text { LEĐA -F }\end{array}$ & $-6,72$ & $\pm 15,45$ & $-2,749$ & 39 & $\mathbf{, 0 0 9 * *}$ \\
\hline $\begin{array}{l}\mathrm{F}_{\max } \text { NOGE-I vs. } \\
\mathrm{F}_{\text {max }} \text { NOGE-F }\end{array}$ & $-7,38$ & $\pm 17,01$ & $-2,743$ & 39 &, $\mathbf{0 0 9 * *}$ \\
\hline
\end{tabular}

Legend: I-initiail measurement; F-final measurement; Mean Differences - diffedence between aritmetica mean initial - final measurement; $S D$ - stanadard deviation; $t$-velue; $d f$ - number of degree of fridom; Sig. $\left(2\right.$-tailed) - level of significance; ${ }^{*}$ - Sig. $<0.05 ;{ }^{*}$ - Sig. $<0.01$ 
Statistically significant differences in the variables results with the above statistical procedure, stafor estimating the maximum isometric force of tistically significant differences were found for all the subjects between the initial and final mea- variables of the maximum isometric force in fasurements were examined with the T-test of the vor of the final measurement, at the significance paired samples (Table 3). Analyzing the obtained level of 0.01 .

Table 4. Significance of differences in explosivity, initial - final measurement (T-test of paired samples)

\begin{tabular}{|l|c|c|c|c|c|}
\hline \multicolumn{1}{|c|}{ Variable } & $\begin{array}{c}\text { Mean } \\
\text { Differences }\end{array}$ & SD & t & df & $\begin{array}{c}\text { Sig. } \\
\text { (2-tailed) }\end{array}$ \\
\hline VIS-I vs. VIS-F & $-0,84$ & $\pm 4,10$ & $-1,297$ & 39 &, 202 \\
\hline DALJ-I vs. DALJ-F & $-8,52$ & $\pm 7,73$ & $-6,976$ & 39 &, $\mathbf{0 0 0} * *$ \\
\hline TR100-I vs. TR100-F & $-0,25$ & $\pm 0,41$ & $-3,938$ & 39 &, $\mathbf{0 0 0} * *$ \\
\hline
\end{tabular}

Legend: I-initiail measurement; $F$ - final measurement; Mean Differences - diffedence between aritmetica mean initial - final measurement; $S D$ - stanadard deviation; $t$ - velue; $d f$ - number of degree of fridom; Sig. (2-tailed) level of significance; ${ }^{*}$ - Sig. $<0.05 ;{ }^{* *}$ - Sig. $<0.01$

Statistically significant differences in the variables ferences were found in the two variables in favor for assessing the explosiveness of the subjects be- of the final measurement (DALJ, TR100) at a sigtween the initial and final measurements were nificance level of 0.01 , while in one variable for the examined with the T-test of the paired samples assessment of explosiveness (VIS) no statistically (Table 4). By analyzing the results obtained by the significant differences were detected between the statistical procedure, statistically significant dif- measurements .

Table 5. Significance of differences in repetative strenght, initial - final measurement (T-test of paired samples)

\begin{tabular}{|l|c|c|c|c|c|}
\hline \multicolumn{1}{|c|}{ Variable } & $\begin{array}{c}\text { Mean } \\
\text { Differences }\end{array}$ & SD & t & df & $\begin{array}{c}\text { Sig. } \\
\text { (2-tailed) }\end{array}$ \\
\hline ZGIB-I vs. ZGIB-F & $-1,60$ & $\pm 2,87$ & $-3,524$ & 39 &, $\mathbf{0 0 1 * *}$ \\
\hline $\begin{array}{l}\text { SKLEK-I vs. SK- } \\
\text { LEK-F }\end{array}$ & $-11,35$ & $\pm 7,72$ & $-9,301$ & 39 &, $\mathbf{0 0 0 * *}$ \\
\hline PTSP-I vs. PTSP-F & $-10,45$ & $\pm 4,67$ & $-14,158$ & 39 &, $\mathbf{0 0 0 * *}$ \\
\hline
\end{tabular}

Legend: I-initiail measurement; $F$ - final measurement; Mean Differences - diffedence between aritmetica mean initial - final measurement; $S D$ - stanadard deviation; $t$ - velue; $d f$ - number of degree of fridom; Sig. (2-tailed) level of significance; ${ }^{*}$ - Sig. $<0.05 ;{ }^{*}-$ Sig. $<0.01$

Statistically significant differences in the variables for estimating the repetitive stenght of the respondents between the initial and final measurements were examined with the T-test for paired by the statistical procedure, statistically significant differences were found in all the variables of the repetitive force in favor of the final measurement, at samples (Table 5). By analyzing the results obtained the significance level of 0.01 .

Table 6. Significance of differences in locomotion, initial - final measurement (T-test of paired samples)

\begin{tabular}{|l|c|c|c|c|c|}
\hline \multicolumn{1}{|c|}{ Variable } & $\begin{array}{c}\text { Mean } \\
\text { Differences }\end{array}$ & SD & t & df & $\begin{array}{c}\text { Sig. } \\
\text { (2-tailed) }\end{array}$ \\
\hline TTEST-I vs. Ttest-F & $-0,25$ & $\pm 0,41$ & $-3,938$ & 39 &, $\mathbf{0 0 0 * *}$ \\
\hline PN-I vs. PN-F & 0,06 & $\pm 0,69$ &, 593 & 39 &, 557 \\
\hline KUPER-I vs. Kuper-F & $-44,87$ & $\pm 181,97$ & $-1,560$ & 39 &, 127 \\
\hline
\end{tabular}

Legend: I-initiail measurement; F - final measurement; Mean Differences - diffedence between aritmetica mean initial - final measurement; $S D$ - stanadard deviation; $t$ - velue; $d f$ - number of degree of fridom; Sig. (2-tailed) - level of significance; ${ }^{*}$ Sig. $<0.05 ;{ }^{*}$ - Sig. $<0.01$ 
Statistically significant differences in the variables for assessing the locomotion of the respondents between the initial and final measurements were examined with the T-test of the paired samples ( $\mathrm{Ta}$ ble 6). Analyzing the results obtained by the above statistical procedure, statistically significant differences were found in one variable in favor of the final measurement (TTEST) at a significance level of 0.01 , while in the two variables for the evaluation of the locomotion (PN, KUPER) no statistically significant differences were detected between the measurements.

\section{CONCLUSION}

By analyzing the obtained data for the group of variables of morphological characteristics after the training program of martial arts techniques in the selected sample and statistical processing, it is evident that there was an increase in value and statistical significance in comparison between the initial and final measurements. According to (Dopsay et al. 2005) who performed the diagnosis of body mass index (BMI) on a sample of students of the Police Academy, aged up to 18.4 to 24.1 years, the results showed that, as a point of inflection between adequate and inadequate BMI values for police officers, critical BMI value over 27.04 $\mathrm{kg} / \mathrm{m} 2$ (medical criterion), respecting BMI value over $27.80 \mathrm{~kg} / \mathrm{m} 2$ (sports-metrology criterion). (Petrice and Jebb 2001) analyzed the assumption on the topic "after the body mass index" and explained that the surrogate anthropometric measure (especially BMI) can provide unreliable data on the fat content in the body. They include: youth and childhood, aging, racial differences, athletes, soldiers and civilian forces, physical training and special clinical circumstances. The quoted authors believe that the body mass index continues to serve well for many purposes, but that it is time to start a gradual evolution beyond that index according to standards separate from the start-up masses of body fat. For a more detailed explanation of the results obtained, it is necessary to indicate the arguments that have come up with Woods et al. (2000) that energy homeostasis, long-term alignment of food intake with energy consumption, is achieved through the control of the size of the meal. Individuals who did not eat enough food to maintain their normal weight have a lower level of signals on adiposity (leptin and insulin) in the blood and brain, and one consequence is that the signal generated by a meal (such as CCK) is less effective in reducing the size of the meal. The assumption is that the reason why there was an increase in the value of morphological characteristics in the sample of the selected sample, which is covered by this research, is actually the concept of basic police training that is carried out in the Republic of Srpska, Ministry of Interior, which implies in-house accommodation with a precisely defined dining time and the quality of the of the meal itself. By reviewing the data obtained for the variables of maximum isometric force after the training program of martial arts techniques in the selected sample, statistical significance in favor of the final measurement is evident. It is assumed that the expected change in the maximum isometric force occurred under the influence of a martial arts training program as a result conducting physical fitness which makes an inevitable segment in the structure of the class. The results obtained by this study certainly lead to the conclusion that the applied training model has had positive effects on the maximum isometric force in the sample of the selected sample, and that the applied training method could be recommended in the professional development of police officers. By looking at the results obtained using the statistical analysis of the T-test for paired samples (Table 4), it is visible that statistical significance was obtained in two variables, while the VIS variable is not the case. Statistically significant differences in the variables for estimating the repetitive power of the respondents between the initial and final measurements after the T-test for the dependent samples (Table 5) were found to exist in all the variables of the repetitive power in favor of the final measurement, at the significance level of 0.01 . Statistical significance between the initial and final measurements of the respondents was determined using the T-test for the paired samples (Table 6) and the obtained result indicates statistically significant differences only in one variable in favor of the final measurement (TTEST) at a significance level of 0.01 , two variables for estimating locomotion (PN, KUPER) did not show statistically significant differences between measurements. By the overall observation of the obtained results, it can be concluded that the training program of martial arts techniques has led to a significant improvement in morphological characteristics, motor and functional abilities in the selected sample. 


\section{REFERENCES}

Copay, Anne. and Charles, Michael. 2001. The influence of grip strength on handgun marksmanship in basic law enforcement training. Policing: An Unternational Journal of Police Strategies \& Management Vol. 24: 32-39.

Dopsaj, Milivoj., Milošević, Milenko., Vučković, Goran., Blagojević, Miroljub., and Mudrić, Radoslav. (2005). Diagnosis of the Body Mass Index of Students of the Police Academy. Sports Medicine, 5 (4): 180-191.

Dopsaj, Milivoj., Blagojević Miroljub, Marinković Boban, Miljuš Dragan., Vučković Goran., Koropanovski Nenad, Ivanović Jelena, Atanasov Dragan amd Janković Radiša. 2010. Modelne karakteristike osnovnih antropometrijskih pokazatelja i bazično - motoričkih sposobnosti (BMS) zdravih i utreniranih mladih osoba oba pola populacioni pokazatelji R. Srbije. Beograd: Kriminalističko-policijska akademija.

Janković, Radiša. 2015. Predikcija rezultata na poligonu za procenu specifične spretnosti policajaca na osnovu morfoloških karakteristika i bazičnih motoričkih sposobnosti. Godišnjak Fakulteta sporta i fizičkog vaspitanja. Beograd, (21), $31-42$.

Milošević, Milenko, Gavrilović Predrag i Ivančević
Vladimir. 1988. Modeliranje i upravljanje sistemom samoodbrane, Naučna Knjiga, Beograd.

Milošević, Milenko, i Zulić, Muharem. 1986. Uticaj nekih dimenzija snage na efikasnost gađanja iz pištolja. 13 maj, MUP SR Srbije, Beograd, 89-92.

Milošević, Milenko. 1985. Određivanje strukture motoričkih svojstava milicionera. Zemun: VŠUP.

Pretice, A. M. and Jebb, S. A. (2001). Beyond body mass index. Obesity Reviews, International Association for the Study of obesity: 2 (3):141 - 147.

Woods, C.S., Schwartz, W. M., Baskin, J.S. \& Seeley, J. R. (2000). Food intake and the Regulation of Body Weight. Annual Review of Psychology. 51, 255-277.

Corresponding author: Željko Mihaljčić Inspector for Special physical education Stojana Jankovića 15, 78000 Banja Luka Bosnia and Hercegovina E-mail: mihafit@gmail.com 